\title{
GEOGRAFIA MISJI LUDOWYCH W DIECEZJI KRAKOWSKIEJ W PIERWSZEJ POŁOWIE XVIII WIEKU W SEWETLE TABEL BPA A. S. ZAEUSKIEGO
}

W świetle dotychczasowej historiografii nie można powiedzieć, że zagadnienie misji wewnętrznych, zwanych inaczej ludowymi, nie było podejmowane. Literatura $\mathrm{z}$ tej dziedziny jest już wcale liczna zarówno w historiografii starszej, jak też bliższej nam czasowo. Ponieważ misje wewnętrzne były prowadzone przez zakony, dlatego prawie wszystkie badania były ujmowane $\mathrm{w}$ ten sam sposób, tzn. poddawano analizie działalność misyjną poszczególnych zakonów w wybranych odcinkach czasowych ${ }^{1}$.

W niniejszym artykule pragniemy zaprezentować nieco inny sposób podejścia do tej problematyki - taki, w którym punktem wyjścia będzie terytorium. W tym wypadku będzie to obszar diecezji krakowskiej. Ujęcie takie jest możliwe dzięki istnieniu specjalnego źródła. Stanowią je pochodzące $\mathrm{z}$ okresu rządzenia diecezją krakowską przez biskupa Andrzeja Stanisława Załuskiego (1746-1758) tzw. Tabele parafii z lat 1747-1749 ${ }^{2}$. Wśród bowiem 140 pytań zamieszczonych w Tabelach jedno dotyczyło misji ludowych ${ }^{3}$. Odpowiedzi udzielone na powyższe pytanie stanowią cenny materiał, który pozwala zobaczyć, jak kształtowała się sytuacja pod względem misji ludowych w diecezji krakowskiej w całym pierwszym półwieczu XVIII stulecia.

$\mathrm{Z}$ dokonanych przez nas zestawień wynika, że sytuacja ta nie przedstawiała się najlepiej, albowiem na ogólną liczbę 756 parafii wykaza-

1 Pełne zestawienie bibliografii na temat misji ludowych podaję w artykule: Jezuickie misje ludowe w latach 1754-1770 w świetle liczb, „Roczniki Humanistyczne" 29 (1981) z. 2 s. 173-198.

2 Tabele te nawiązują bezpośrednio do akt wizytacji tegoż biskupa i sa tabelarycznym przedstawieniem ich treści. Znajdują się w Archiwum Kurii Metropolitalnej w Krakowie, oprawione w $12 \mathrm{ksiąg}$ dużego formatu. Tabela każdej parafii nosi tytul: Tabella eorum, super quibus in visitatione inquirendum est, wskazujący na to, że dotyczą one tych samych spraw, do których odnoszą się akta wizytacji. Kwestionariusz Tabel w zasadzie pokrywa się z kwestionariuszem wizytacji. Obejmuje on 140 punktów wydrukowanych na dużych arkuszach jako tytuły rubryk, w które wpisano w skróceniu odpowiednie dane, szerzej opisane w samych aktach wizytacji.

\& Jest ono sformułowane w sposób bardzo ogólny, po prostu brzmi: „missio"$\mathrm{Na}$ skutek tego istniała możliwość dawania bardzo różnych odpowiedzi. 
nych w Tabelach misje w pierwszej połowie XVIII w. były przeprowadzone tylko w 174. Oznacza to, że w okresie równym mniej więcej 50 latom misjami objęto zaledwie $23 \%$ parafii, a więc nawet nie całą czwartą część. Przy czym należy dodać, że w przypadku czterech parafii chodziło prawdopodobnie o tzw. misje mniejsze, jakie zwykli głosić jezuici w większe święta roku liturgicznego ${ }^{4}$. Odnośnie do trzech parafii: Dzierzkowice (dek. Urzędów), Jeżowe (dek. Rudnik) i Rudnik, jest to zupełnie pewne w świetle zamieszczonych w źródle odpowiedzi. W przypadku pierwszej powiedziano: „Quolibet anno bis per Patres Societatis Lublinensis". Zawarta w odpowiedzi informacja o odbywaniu każdego roku dwu misji wskazuje wyraźnie, że chodziło tutaj o misje małe. Przy parafii Jeżowe odpowiedź brzmiała: „Nulla [domyślne missio] fuit formalis, tantum pro Festis Ressurectionis". Przy parafii zaś Rudnik powiedziano, co następuje: „Per Patres Societatis Jesu Festorum Nativitatis et Paschalis nunc autem catechismus et concio diebus festivis". Nie ma tej pewności w odniesieniu do czwartej parafii Kurów, położonej w dekanacie kazimierskim. Przekazana dla niej odpowiedź brzmiała: „Formalis [domyślne - missio] nulla fuit, anno praeterito Lublino fuerant Patres Misionarij, qui cathechizabant et exhortationes habebant". Z powyższej odpowiedzi trudno wywnioskować, o jaką w tej parafii misję chodziło. Nie wydaje się, abyśmy mieli tutaj do czynienia z misją właściwą. Gdyby faktycznie chodziło o taką misję, autor nie dawałby takiej opisowej odpowiedzi. Poza tym nie wiadomo, czy prowadzącymi misję byli jezuici, czy misjonarze św. Wincentego à Paulo, gdyż określenie ,patres misjonarij” może się odnosić zarówno do jezuitów, jak też do zakonu misjonarzy. Oba bowiem te zakony posiadały swoje placówki w Lublinie. Misjonarze św. Wincentego à Paulo, o ile nam wiadomo, nie prowadzili misji małych. W rezultacie więc misje właściwe, zwane inaczej większymi lub pokutnymi, były przeprowadzone tylko w 170 parafiach ${ }^{5}$.

Chociaż prowadzenie misji nie było programowane według jednostek administracji kościelnej, to wydaje się, że pożyteczną będzie rzeczą zapoznanie się, jak kształtowała się pod tym względem sytuacja w obrębie poszczególnych dekanatów ${ }^{6}$. Problem ten ilustruje zamieszczona poniżej tabela.

${ }^{4}$ Szerzej na temat misji mniejszych patrz przypis 1 .

5 Istnienie, obok odpowiedzi pozytywnych, odpowiedzi wyraźnie negatywnych, tzn. takich, które stwierdzały brak misji, zdaje się sugerować, że przekazany stan liczbowy misji, jeśli nie oddaje faktycznego stanu, to był na pewno do niego bardzo zbliżony.

- $\mathrm{Z}$ faktem planowania misji w dekanatach spotykamy się dopiero $\mathrm{w}$ XX wieku. Przykładem tego jest diecezja kielecka, gdzie biskup ustalił plan misji ludowych w diecezji na okres od 1934 do 1937 r. (A. S o bc zyński, Misje parafialne w diecezji kieleckiej, „Przegląd Diecezjalny” 24, 1937, nr 1 s. 20-22). 
Täb. 1

LICZBIA DEEIANATOW Z LICZBAZ PARAFII OBJETYYCH MISJIAMI

\begin{tabular}{lrrrrrrrrrrrr}
\hline Parafie & 0 & 1 & 2 & $\mathbf{3}$ & 4 & $\mathbf{5}$ & $\mathbf{6}$ & $\mathbf{7}$ & $\mathbf{8}$ & $\mathbf{9}$ & 10 & 11 \\
Dekanaty & 2 & 11 & 10 & 7 & 3 & 1 & $\mathbf{6}$ & $\mathbf{2}$ & $\mathbf{2}$ & 0 & 3 & 1 \\
\hline
\end{tabular}

Jak wynika z tabeli, najwyższa liczba parafii objętych misjami w jednym dekanacie $\mathrm{w}$ badanym półwieczu dochodziła do 11. Tak wysoką liczbą odznaczał się tylko jeden dekanat, mianowicie Nowy Targ, który według Tabel liczył 14 parafii, natomiast w 1772 r. - według obliczeń S. Litaka - 12 świątyń parafialnych i 17 kościołów filialnych ?. Naszym zdaniem ta wysoka liczba parafii objętych misjami nie była przypadkowa. W fakcie tym należy upatrywać przejaw świadomej akcji duszpasterskiej prowadzonej przez Kościół, a konkretnie przez zakony. Dekanat ten ze względu na swoje górskie położenie miał wyjątkowo rzadką sieć parafialną. Na skutek tego mieszkańcy tych terenów mieli utrudnione wypełnianie obowiązków religijnych. To sprawiało, że ich poziom życia religijnego był zapewne niższy aniżeli na innych obszarach diecezji. W tym właśnie celu jezuici założyli swoją stację misyjną w parafii Jordanów, której celem miało być objęcie opieką duszpasterską ludności góralskiej tego regionu ${ }^{8}$. Jest więc rzeczą wielce prawdopodobną, że ta duża liczba parafii objętych misjami była wyrazem i przejawem tej opieki. Zresztą do pewnego stopnia potwierdza to również samo źródło. W przypadku parafii Łętownia w okresie od 1736 do 1748 były przeprowadzone dwie serie misji, z których jedną głosili misjonarze ze Stradomia, drugą zaś jezuici. Być może, że byli to jezuici ze wspomnianej stacji jordanowskiej, którzy w r. 1748 (źródło używa określenia — „actualiter”) prowadzili misję również u siebie w parfii Jordanów.

Kolejną najwyższą liczbę parafii objętych misjami w jednym dekanacie stanowiła, według Tabel, liczba 10 parafii. Takie liczby parafii stwierdziliśmy $\mathrm{w}$ trzech dekanatach: położonym na północny zachód od Krakowa dekanacie Skała, w sąsiadującym $\mathrm{z}$ tym ostatnim dekanacie Lelów oraz pozostającym poza granicą państwa dekanacie Pszczyna. Je-

7 S. Litak, Struktura terytorialna Kościoza kacińskiego $w$ Polsce w 1772 roku, Lublin 1980, s. $200-201$.

- Stanisław Z Załęski w swej pracy poświęconej jezuitom (Jezuici w Polsce, t. IV (2, Kraków 1904, s. 798) tak pisał na ten temat: „Dla górali polskich i śląskich, bo i tych niezaniedbano, przeznaczeni byli osobni misyonarze podgórscy, submontani. Mieszkali w kolegium, a w XVIII wieku mieli stałe placówki misyjne w Jordanowie, Białej i Żywcu, należące do kolegium św. Piotra [w Krakowie]. Jordanów nad Skawiną trzymali przez dłuższy czas Jezuici prawem zastawnem od kaszt. kamien. Mąkowieckiego i kolo r. 1710 postawili tam najprzód kościółek, potem $1726 \mathrm{r}$. domek dla dwóch misyonarzy, którzy już $1712 \mathrm{r}$. przy pomocy innych Jezuitów z kolegium dawali misye w Jordanowie, Jeleśni, Rzezawie, Radłowie, Więcławicach. Rok rocznie aż do 1773 r. ponawiały si ę prace misyjne w całej okolicy. 
śli chodzi o ten ostatni, było to prawie wyłącznie zasługą jezuitów. Na 10 parafii objętych misjami, w 8 prowadzili je jezuici, w jednej (Mikołów) - misjonarze. Tylko w parafii Chełm Wielki nie wiadomo, kto prowadził misję. $\mathrm{Z}$ innych momentów zasługuje na uwagę fakt, że oprócz trzech misji: w Chełmie Wielkim przeprowadzonej w r. 1743, w Miedźnej - w r. 1726 i w Mikołowie z r. 1729, wszystkie pozostałe były głoszone w latach trzydziestych, konkretnie w okresie od roku 1735 do $1739^{\circ}$. W pięcioleciu tym przeprowadzono misje w następujących parafiach: Bojszowy (1737), Bieroń (1736), Brzeźce (1737), Lędziny (1736), miasto Pszczyna (1735), Suszec (1739) i Tychy (1738).

Zwracamy uwage na ten moment chronologiczny, gdyż był to jedyny dekanat, w którym występowała taka koncentracja misji w krótkim okresie czasu. Czy i jakie kryły się za tym przyczyny, nie wiadomo. Wprawdzie w dwu pozostałych, wcześniej wymienionych dekanatach można doszukać się pewnego okresu o zwiększonej liczbie misji, ale nie w takiej proporcji. Spośród 20 parafii tych dekanatów objętych misjami, w dziesięciu przeprowadzono je w latach czterdziestych, w dziewięciu w latach trzydziestych oraz w jednej w roku 1720 . Wyróżniającymi się latami, które częściej się powtarzały był rok 1742 i 1743. Dlaczego właśnie $w$ trzech wymienionych dekanatach w tak wielu parafiach przeprowadzono misje, trudno nam powiedzieć. W przypadku Lelowa i Skały uderzający jest fakt ich sąsiedztwa. Być może, że właśnie po tej linii winno się szukać wyjaśnienia tak dużej częstotliwości misji. Tym bardziej, że sąsiadujący od południa z dekanatem Skała dekanat nowogórski należał również do bardziej uprzywilejowanych. Spośród 18 parafii wykazanych w Tabelach $8 \mathrm{z}$ nich było w omawianym półwieczu objętych misjami. Tyleż samo posiadał ich jeszcze tylko jeden dekanat, mianowicie leżący na północno-zachodnim krańcu diecezji dekanat parczewski. W dalszej kolejności pozostawały dwa dekanaty, które posiadały po 7 parafii objętych misjami. Stanowiły je sąsiadujący od wschodu z dekanatem nowotarskim dekanat Nowy Sącz oraz niewielki, liczący według Tabel 14 parafii, dekanat witowski. Dekanatów liczących po 6 parafii objętych misjami było aż 6 . Były to następujące dekanaty: wchodzący w skład archidiakonatu lubelskiego dekanat kazimierski, sąsiadujący bezpośrednio z dekanatami krakowskim i skalskim dekanat Proszowice, przynależny do wspomnianego już archidiakonatu

9 W źródle stosowano dwa rodzaje podawania dat rocznych: raz podawano konkretny rok, innym razem informowano przed iloma laty była przeprowadzona misja. W tym ostatnim przypadku obliczaliśmy datę roczną sami. Dokonywaliśmy tego $\mathrm{w}$ ten sposób, że odejmowaliśmy podaną liczbę lat od roku 1748. Wprawdzie. Tabele pochodzą $\mathrm{z}$ dwu lat, tzn. $\mathrm{z}$ r. $1747 \mathrm{i} 1748$, ale ponieważ nie były one podawane dla wszystkich parafii, dlatego dla wszystkich przyjęliśmy jedną datę roczną, właśnie ów rok 1748 . 
lubelskiego dekanat urzędowski, leżący na południowy wschód od Krakowa dekanat Wieliczka oraz sąsiadujące ze sobą podgórskie dekanaty Zator i Żywiec.

Wśród pozostałych dekanatów, nie licząc jednego, który posiadał pięć parafii i trzech liczących po cztery parafie objęte misjami, gros stanowiły dekanaty o bardzo niewielkich liczbach parafii, a mianowicie: 7 z nich posiadało po trzy parafie, 10 - po dwie oraz 11 - po jednej parafii, w których przeprowadzono misje w interesującym nas półwieczu. Łącznie było ich 28, czyli więcej aniżeli połowa w stosunku do wszystkich dekanatów objętych Tabelami. Stwierdziliśmy też, że dwa dekanaty nie miały $w$ ogóle parafii objętych misjami. Był to dekanat solecki i jędrzejowski, z tym że ten drugi nie powinien być zasadniczo brany pod uwagę. W Tabelach wykazano dla niego tylko jedną parafię. Przez to absolutnie nie może on być reprezentatywny.

W świetle dokonanej analizy wyraźnie widać, że najwięcej parafii, w których przeprowadzono misje w pierwszej połowie XVIII w., posiadały dwa regiony diecezji: obszar położony na północny-zachód od Krakowa oraz dekanat parczewski. Wyłom w pierwszym stanowiły jedynie: położony pomiędzy dekanatami lelowskim, skalskim i nowogórskim niewielki dekanat $\mathrm{z}$ siedzibą $\mathrm{w}$ Wolbromiu oraz sąsiadujący od północy $\mathrm{z}$ dekanatem pszczyńskim, leżący poza granicą państwa dekanat bytomski.

Kolejne ważne zagadnienie, jakie nasuwa się $w$ rozważaniach na temat misji stanowi udział w nich poszczególnych zakonów. Zagadnienie to poruszyliśmy już częściowo przy analizie sytuacji w dekanacie Pszczyna. Obecnie należałoby rozpatrzyć to bardziej generalnie, tzn. w kontekście całej diecezji. Niestety wielka fragmentaryczność informacji przekazanych w tym zakresie nie pozwala na wyczerpujące przedstawienie tego problemu i uzyskanie pełniejszego obrazu. Kompletność informacji przekazanych w przypadku dekanatu Pszczyna stanowi w całości Tabel jedyny wyjątek. W żadnym $\mathrm{z}$ pozostałych dekanatów nie podano z taką konsekwencją informacji o tym, kto $\mathrm{w}$ danej parafii prowadził misję.

W analizowanym półwieczu misje prowadziły w diecezji krakowskiej tylko dwa zakony: jezuici i misjonarze. Tak przynajmniej zdaje się sugerować nasze źródło. Działalność pierwszych jest potwierdzona w 36 parafiach, drugich natomiast w $25{ }^{10}$. Jak pamiętamy wszystkich parafii objętych misjami było 174 . W związku z powyższym nasuwają się dwa

${ }^{10} \mathrm{Za}$ misje jezuickie uznaliśmy tylko te, przy których jest to wyraźnie zaznaczone, pozostałe uznaliśmy za misje księży misjonarzy św. Wincentego à Paulo. Nadmieniam o tym dlatego, że są wypadki, w których nie wiadomo, w jakim znaczeniu użyto określenia misjonarze: czy na oznaczenie zakonu księży misjonarzy, czy w sensie ogólnym dla nazwania kapłanów głoszących misje. 
dość istotne pytania: kto wobec tego prowadził misje w pozostałych $111^{11}$ parafiach oraz pytanie drugie - dlaczego nie podano na ten temat informacji? Odpowiedź na drugie pytanie jest bardzo prosta. Kwestionariusz Tabel tego nie wymagał, więc takich informacji nie zamieszczano. Jeżeli znalazły się one dla wspomnianych 61 parafii, to zawdzięczamy je gorliwości odpowiadających. Gdy chodzi natomiast o pytanie pierwsze, sprawa jest znacznie trudniejsza. Jesteśmy zdania, że wszystkie pozostałe misje również prowadzili bądź to jezuici, bądź to misjonarze. Gdyby bowiem czynił to jakiś inny zakon, dla którego działalność misyjna nie była pierwszoplanową, to wolno się spodziewać, że nawet przy braku wspomnianego pytania w kwestionariuszu odpowiadający przekazaliby taką informację. Czy tak faktycznie było, tzn. czy inne zakony prowadziły misje, nie da się stwierdzić. Jeżeli nawet przyjmiemy, że tak było, to prawdopodobnie w njewielkim stopniu i na pewno nie popełniamy błędu zakładając, iż w diecezji krakowskiej w pierwszej połowie XVIII wieku misje prowadziły jedynie dwa zakony: jezuici i misjonarze. Szkoda tylko, że na skutek braku wspomnianych informacji nie można ocenić udziału każdego $\mathrm{z}$ obu zakonów przy generalnym ujęciu zagadnienia oraz ustalić na ile znane liczby ulegną zmianie i na czyją korzyść.

Jak przedstawiały się w poszczególnych dekanatach liczby parafii, w których jezuici i misjonarze głosili misje ilustruje kolejne zestawienie. Pomijamy w nim oczywiście dekanaty, w których nie występowały parafie objęte misjami.

Jezuici objęli swymi misjami najwięcej parafii (poza wzmiankowanym już dekanatem pszczyńskim) w dekanacie żywieckim (4). Natomiast w zasięgu oddziaływania misyjnego zakonu misjonarzy, o ile o takim przy tym niepełnym obrazie można mówić, znalazły się cztery dekanaty: Połaniec, Skała, Kazimierz i Opatowiec. W dwu pierwszych misjonarze obsłużyli po cztery parafie, w dwu następnych — po trzy. W pozostałych dekanatach $\mathrm{w}$ grę wchodziły dwie lub jedna parafia, tak u jezuitów, jak też u misjonarzy. Interesującą rzeczą byłoby ustalenie, z których placówek tych zakonów wyruszały ekipy misjonarskie do akcji misyjnych. Jednakże nawet $\mathrm{w}$ odniesieniu do owych 61 parafii nie wszędzie przekazano tego rodzaju dane. Wiadomo, że ze strony misjonarzy w prowadzenie misji były zaangażowane następujące placówki: krakowska na Stradomiu, warszawska św. Krzyża i lubelska. W przypadku tej ostatniej niewątpliwie chodziło o posiadaną przez misjonarzy parafię w Dysie, która ze względu na bliską odległość od Lublina występowała

${ }^{11}$ Liczba parafii nie pokrywa się z liczbą misji, gdyż w kilku parafiach występowały podwójne misje $\mathrm{w}$ badanym półwieczu. 
Tab. 2

LICZBA PARAFII W DEKANATACH, W KTORYCH JEZUICI I MISJONARZE PRZEPROWADZILI MISJE W DIECEZJI KRAKOWSKIEJ W 1. POE. XVIII

\begin{tabular}{|c|c|c|c|c|c|}
\hline Lp. Dekanat & jezuici & $\begin{array}{c}\text { misjo- } \\
\text { narze }\end{array}$ & Lp. Dekanat & jezuici & $\begin{array}{c}\text { misjo- } \\
\text { narze }\end{array}$ \\
\hline 1. Chodel & - & 1 & 15. Rudnik & 2 & - \\
\hline 2. Dobczyce & 2 & 1 & 16. Skała & - & 4 \\
\hline 3. Kazimierz & - & 3 & 17. Sokolina & - & 1 \\
\hline 4. Koprzywnica & 一 & 1 & 18. Stężyca & - & 1 \\
\hline 5. Lelów & 1 & - & 19. Urzędów & 2 & 1 \\
\hline 6. Lipnica Mur. & - & 1 & 20. Wieliczka & 1 & 2 \\
\hline 7. Miechocin & - & 2 & 21. Witów & - & 2 \\
\hline 8. Nowy Targ & 2 & 1 & 22. Wolbrom & 1 & - \\
\hline 9. Opatowiec & - & 3 & 23. Zator & 1 & - \\
\hline 10. Opatów & - & 1 & 24. Zawichost & 1 & - \\
\hline 11. Pacanów & 一 & 1 & 25. Zwoleń & - & 1 \\
\hline 12. Parczew & - & 4 & 26. Żmigród & - & 2 \\
\hline 13. Połaniec & - & 2 & 27. Żywiec & 4 & - \\
\hline 14. Pszczyna & 8 & 1 & Razem & 25 & 36 \\
\hline
\end{tabular}

pod mianem lubelskiej, także $\mathrm{w}$ innych źródłach ${ }^{12}$. Misjonarze stradomscy przeprowadzili misje w następujących parafiach: Bejsce, Korczyn Nowy i Żabno, położonych na terenie dekanatu Opatowiec; Niedźwiec i Smardzewice leżących w dekanacie Skała; Dukla i Jaśliska przynależnych do dekanatu Żmigród oraz w parafii Łętownia (dek. Nowy Targ), Mszana Dolna (dek. Dobczyce), Stopnica (dek. Pacanów), Rachwałowice (dek. Witów) i Żegocina (dek. Lipnica Murowana). W zasięgu działalności misyjnej ekipy lubelskiej znalazły się następujące parafie: Końskowola i Kurów z dekanatu Kazimierz; Kiełczyna i Włostów z dekanatu Połaniec oraz Modliborzyce z dekanatu Urzędów; Ostrowiec Świętokrzyski z dekanatu Opatów i Samogoszcz z dekanatu Stężyca. Ekipa z Warszawy przeprowadziła misje w parafii Swierże Górne położonej w dekanacie Zwoleń. Dla jezuitów prowadzenie misji potwierdzone jest w odniesieniu do czterech placówek: Lublina, Jordanowa, Koniecpola i Żywca. Ekipa lubelska przeprowadziła misje w parafii Dzierzkowice i Urzędów, obie położne w dekanacie Urzędów. Misjonarze z Jordanowa głosili misje w samym Jordanowie i w parafii Lubień z dekanatu Dobczyce. Ekipa z Koniecpola obsłużyła swymi misjami parafię Kidów z dekanatu Wolbrom i Polesie, położoną w dekanacie Lelów, natomiast eki-

12 Archiwum Nuncjatury Warszawskiej w Archiwum Watykańskim vol. $122 \mathrm{k}$. :311-311 v: Tabella omnium domorum Congregationis Sacerdotum Saecularium Missionis in Regno Poloniae ac provinciis ei annexis aut ab recens avulsis existentium exhibens ordine alphabetico loca earundem domorum, numerum personarum eas incolentium ac functiones, quae in illis exerceri solent [z końca 1773]. 
pa z Żywca prowadziła misje w parafii Czyżów, położonej w dek. Zawichost, i w parafii Rychwałd, leżącej w tym samym dekanacie co placówka, tzn. w dekanacie Żywiec. Fragmentaryczność powyższych danych nie pozwala niestety na wyciągnięcie $\mathrm{z}$ nich jakiś bardziej ogólnych wniosków.

Innym ważnym zagadnieniem jest sprawa chronologii. Chodzi tutaj o daty roczne przeprowadzonych misji w owych 174 parafiach. Tabele wykazują w tym względzie o wiele większą systematyczność i konsekwencję aniżeli w omawianej powyżej sprawie. Przypadki, w których nie podano roku przeprowadzenia misji należą do rzadkości. Pozwala to na dokonanie pewnych zestawień i porównań ważnych dla przyszłych badań nad misjami.

Jeżeli podzielimy całe półwiecze na 5 dziesięcioleci i w ich ramach zestawimy interesujące nas misje wówczas otrzymamy bardzo pouczający i wymowny obraz. Okaże się, że najbardziej bogatym w misje był okres od 1740 do 1748. Przeprowadzono wtedy 74 misje. W stosunku do ogólnej liczby 156 wszystkich misji, dla których podano dokładne daty, stanowiło to prawie $50 \%$. W miarę cofania się wstecz w każdym dziesięcioleciu było mniej misji. I tak w okresie od 1731 do 1740 przeprowadzono ich 54, co stanowiło ok. 35\%, w latach od 1721 do 1730 już tylko 21, zaś w okresie od 1711 do 1720 zaledwie 5 misji. Najbardziej ubogie pod tym względem było dziesięciolecie trwające od r. 1700 (a właściwie od r. 1698 do 1710). Dla okresu tego zarejestrowaliśmy tylko dwie misje, z których jedną przeprowadzono w r. 1701 w parafii Gniazda na Spiszu, a drugą właśnie we wspomnianym r. 1698 w parafii Sanka, położonej w dekanacie Nowa Góra.

Dostrzeżone zjawisko zmniejszania się liczby misji w miarę oddalania się od daty powstania źródła można tłumaczyć dwoma faktami. Po pierwsze trzeba przyjąć, że wynikało to z charakteru samego źródła, a mianowicie, że dla wcześniejszych lat mniej pamiętano misji niż dla kilku czy kilkunastu lat ostatnich. Śmiało można założyć, że odpowiadający rzadko sięgali do akt, opierali się raczej na pamięci własnej lub osób im bliskich. Stąd właśnie ta duża różnica pomiędzy pierwszym i drugim dziesięcioleciem $\mathrm{z}$ jednej strony i trzema, a właściwie dwoma ostatnimi. Po drugie pozostawało to w jakimś związku z działalnością duszpasterską poszczególnych biskupów. Takie przypuszczenie zdaje się sugerować wyjątkowa duża liczba przeprowadzonych misji w okresie trzech pierwszych lat rządów diecezją inicjatora Tabel - biskupa A. S. Załuskiego. Od roku 1746, w którym Załuski objął biskupią stolicę krakowską przeprowadzono misje w 26 parafiach, co w stosunku do wspomnianej liczby 156 wszystkich misji ze znanym czasem stanowiło blisko $17 \%$. 
Stwierdzony na początku rozważań fakt nienajlepszej sytuacji w zakresie powszechności i częstotliwości praktyki misyjnej w diecezji zdają się także potwierdzać występujące odpowiedzi negatywne, tzn. takie, które wyraźnie stwierdzały brak misji. Mimo swojej stereotypowości i szablonowości kryły one w sobie pewne treści, które rzucają światło na sytuację, jaka występowała w poszczególnych parafiach. Jedną z nich była formuła, w której stwierdzano, że misji w parafii nie było od niepamiętnych czasów (,ab immemorabili tempore” lub ,ab antiquo tempore"). Jeśli formuła ta nie służyła do zwykłego stwierdzenia braku misji, ale oddawała faktycznie moment czasowy, to wymowa jej jest jednoznaczna. Przy takim jej rozumieniu w ponad 80 parafiach (dokładnie w 82), które w stosunku do 756 wszystkich parafii wyszczególnionych $\mathrm{w}$ Tabelach stanowiły ponad $10 \%$, nie było misji od niepamiętnych czasów. Wprawdzie nie da się ustalić, o jaki okres mogło tutaj chodzić, pewną jest jednak rzeczą, że nie chodziło tutaj o okres pięciu lub dziesięciu lat, lecz znacznie dłuższy. W grę mógł wchodzić okres jednego pokolenia lub nawet całego półwiecza. Zresztą w każdej parafii formuła ta wyrażała inny odcinek czasu, zawsze jednak na pewno dłuższy niż sięgała pamięć współcześnie żyjących i pracujących duszpastersko w parafiach kapłanów. Najliczniej występowały tego typu parafie w pięciu dekanatach, a mianowicie: w dekanacie nowosądeckim (15), bodzentyńskim (14), kunowskim (12), jasielskim (11) i ropczyckim (9).

Do tej samej kategorii parafii, jak się wydaje, należy zaliczyć te, w których nie pamiętano, kiedy były misje. Łacińskie formuły wyrażające ten fakt brzmiały bardzo różnie, na przykład: ,non est memoria illius existentiae”, ,non recordatur aliquando extitit” lub „quando hic fuit non extat memoria" itp. Od poprzednich różniły się, jeśli chodzi o informację, jedynie brakiem podania długości okresu, w których nie było misji. Brak przy ich opisie owego krótkiego dopowiedzenia ,od niepamiętnych czasów" sugeruje, że okres ten był na pewno znacznie krótszy. Wolno przyjąć, że nie sięgał w. XVII. Niezależnie jednak od tego, jak długi był ten czas, sytuacja w obu kategoriach parafii była, rzec by można, identyczna. Na tej podstawie można je traktować łącznie. Według dokonanych obliczeń było tego rodzaju parafii 164, co w stosunku do znanej już liczby 756 wszystkich parafii stanowiło prawie $22 \%{ }^{18}$.

13 Wielce wymowna jest też sytuacja, z jaką spotykamy się w parafii Niedrzwica (dek. Chodel). Na pytanie o misje autor odpowiedział, że nie ma zwyczaju (domyślne) odprawiania misji (,non est in usu”). Jeśli przyjmiemy dosłowne rozumienie tej odpowiedzi, to należy uznać, że nie wystawia ona najlepszej opinii tejże parafii. Sugerowałoby to, że jeśli zjawisko misji nie było czymś obcym dla rządzących tą parafią, to $\mathrm{w}$ każdym razie nie wykazywali oni w tym zakresie większego zainteresowania. Wydaje się jednak, że odpowiedź tę należy interpretować 
Dosyć istotna jest też inna formuła, w której stwierdzano, że w parafii nie było nigdy misji. W pierwszej chwili wydaje się ona zupełnie jasna i zrozumiała. W rzeczywistości jednak jej interpretacja nastręcza pewne trudności. Nieprawdopodobną rzeczą wydaje się, że wyrażała ona absolutny brak misji w jakiejś parafii na przestrzeni jej dziejów od czasu, kiedy praktyka misji była stosowana. Naszym zdaniem wyrażano w ten sposób brak misji w danej parafii za pamięci odpowiadającego. Za takim jej rozumieniem zdaje się przemawiać same źródło, konkretnie formuła opisująca sytuacje, jaka miała miejsce $\mathrm{w}$ parafii Wsola w dekanacie Radom. Przy opisie tej parafii powiedziano w taki sposób: misji w ogóle nie było albo się nie pamięta (,,aut nunquam fuit aut non est traditum memoriae"). Przy takim rozumieniu tejże formuły, jakie proponujemy, jest ona bardzo zbliżona do poprzedniej. Opisaną przez nią sytuację posiadało w świetle Tabel 48 parafii. Najwięcej znajdowało się ich w dekanacie Nowa Góra (18) i Bytom (8). Nie ulega wątpliwości, że parafie te należy doliczyć do obu kategorii parafii poprzednio omówionych. Łącznie było więc w diecezji aż 294 parafie, w których nie było misji, powiedziawszy łagodnie, od dosyć długiego czasu. Wymowa tego faktu stanie się pełniejsza, gdy uświadomimy sobie, że liczba ta w stosunku do przywoływanych już wielokrotnie 756 wszystkich parafii stanowiła prawie 40\% (dokładnie 38,8\%) i przewyższała o 120 parafie, w których misje były przeprowadzone. Pierwszych, jak pamiętamy, było 174, natomiast tych ostatnich - 294. W kontekście przytoczonych liczb jeszcze raz potwierdza się to, że sytuacja w diecezji krakowskiej pod względem praktyki misji ludowych nie przedstawiała się, powiedzmy otwarcie, najlepiej. Blisko 40\% parafii nie miało u siebie misji od niepamiętnych czasów. Dodajmy jednak od razu, że sytuacja ta nie jest ostateczna. Mamy bowiem do odnotowania także pewne zjawiska, które naświetlają ją od innej, bardziej pozytywnej strony. Istnieją w źródle wyraźne przykłady na to, że gdy w jakiejś parafii były organizowane misje, to brali w nich udział nie tylko wierni z tejże parafii, ale także z sąsiednich parafii. Sytuację taką spotykamy w 27 parafiach ${ }^{14}$. Najwięcej tego rodzaju parafii stwierdziliśmy $w$ dekanacie Lelów - 12, przy czym warty jest odnotowania fakt, że wierni dziewięciu spośród tych parafii uczestniczyli w misjach prowadzonych $\mathrm{w}$

nieco szerzej, tzn. przyjąć, że wyrażono w ten sposób fakt, iż od dłuższego czasu już nie było misji. Okres był tak długi, że z powodzeniem można było powiedzieć, że nie ma zwyczaju odprawiania misji w tej parafii.

${ }_{14}$ Należy wyjaśnić, że i tutaj zachodziły pewne różnice. Sprowadzały się one do tego, że nie we wszystkich przypadkach udział wiernych z sąsiednich parafii był wprost potwierdzony. Opierając się jednak na kontekście źródłowym, przyjmujemy, że udział ten miał miejsce. $\mathrm{Na}$ tej podstawie wszystkie parafie traktujemy łącznie. 
stolicy dekanatu, tzn. w Lelowie. Przy okazji należy dodać, że misja w I elowie miała w ogóle wyjątkowy charakter. Była bowiem zorganizowana $\mathrm{z}$ dużym nakładem pracy i wiele kosztowała. Zapewne przez to stała się głośna i ściągnęła wiernych z tak wielu parafii. Dwa kolejne miejsca zajmowały dekanat Nowy Sącz i Skała. W pierwszym uczestniczyli $\mathrm{w}$ misjach wierni $\mathrm{z}$ sześciu parafii, w drugim natomiast $\mathrm{z}$ czterech parafii. Poza tymi trzema dekanatami podobna sytuacja, lecz w znacznie mniejszym stopniu miała miejsce jeszcze w czterech dekanatach: Kunów, Radom, Rudnik i Wolbrom. W trzech pierwszych uczestniczyli w misjach w sąsiednich parafiach wierni z jednej parafii, w ostatnim wierni z 2 parafii. W tym miejscu należy wyjaśnić, że autorzy, podając powyższe informacje o uczestnictwie w misjach $w$ innych parafiach, mieli na uwadze nie tyle korzyści duchowe wynoszone z misji, ile raczej moment usprawiedliwienia, dlaczego nie było misji w ich parafiach. Mówimy o tym, gdyż wynika z tego bardzo ważki wniosek, ten mianowicie, że brak misji uchodził za coś odbjegającego od normy.

Skoro mowa o okolicznościach, którymi usprawiedliwiano brak misji, było ich znacznie więcej. Jedną z częściej powtarzających się było powolywanie się na to, że w danej parafii w niedziele i święta są głoszone kazania i jest prowadzona katechizacja, lub że miejscowi duszpasterze są wspomagani przez kapłanów zakonnych. Na taką okoliczność powołano się $\mathrm{w}$ dziesięciu parafiach. Na przykład w parafii Sancygniów (dek. Sokolina) napisano w następujący sposób: „Modernus Rector semper populum ante confessionem et communionem instruit per modum missionis". W przypadku parafii Żarnowiec (dek. Wolbrom) odpowiedź brzmiała: „Non fuit ex quo sunt duo vicarij ad catechizandum et conciones". Podobną odpowiedź zamieszczono w przypadku parafii Więcławice (dek. Proszowice): „Non est fundata inter fines Parochiae Festis tamen Solemnioribus Reverendi Vicarij adjuvantur in Confessionibus a PP. Societatis". Nie mnożąc przykładów, przytoczmy jeszcze jeden dla parafii Pysznica (dek. Rudnik). Udzielona odpowiedź brzmiała: „Non fuit tantum Ordinaria doctrina catechistica Diebus Dominicis et conciones diebus Festivis".

W przekonaniu autorów odpowiedzi podobnie czyniło zadość misjom prowadzenie parafii przez jakiś zakon. Z opinią taką wyrażoną za każdym razem $\mathrm{w}$ innej formie spotykamy się $\mathrm{w}$ trzech parafiach: Brzesko Nowe (dek. Witów), Dys (dek. Parczew) i Żyrzyn (dek. Kazimierz). W przypadku pierwszej powiedziano wprost, że misji nie było, gdyż parafia jest obsługiwana przez kapłanów zakonnych (,nulla exstitit cum ipsi A. RR. ac Religiosi PP. in vinea ista laborant"). Jak wiadomo chodziło tutaj o posiadających tam swoją placówkę norbertanów. Bardzo ciekawie określono sytuację, jaka miała miejsce w prowadzonej przez 
misjonarzy parafii Dys koło Lublina. W odpowiedzi na pytanie, czy była tam przeprowadzona misja, autor użył określenia „,continua”. Jest to bardzo interesująca i wymowna odpowiedź. Pomijając fakt pewnej przesady, jaką odpowiedź ta może zawierać, wynika z niej, jak bardzo ceniono prowadzenie parafii przez zakony. Fakt ten potraktowano jako ciągłą misję, bo nie sądzimy, że chodziło tutaj o misję w dosłownym znaczeniu, która trwałaby ciągle. Takich misji nie było. Analogiczna sytuacja wystąpiła w parafii Żyrzyn, gdzie autor na pytanie o misję dał następującą odpowiedź: „nulla fuit, sed quia PP. Societatis Jesu manent".

Dla znajomości rzeczywistego obrazu sytuacji, jaki miał miejsce w diecezji, należy uwzględnić jeszcze jeden typ parafii, mianowicie te, w których planowano przeprowadzenie misji. Z naszych obliczeń wynika, że co najmniej w 8 parafiach było przewidziane przeprowadzenie misji w najbliższym czasie. Oczywiście ze zjawiskiem tym spotykamy się $\mathrm{w}$ parafiach, w których dawno już nie było misji. Z tej racji tego rodzaju informacje były podawane jako pewnego rodzaju usprawiedliwienie. Parafie te występowały w czterech dekanatach, mianowicie: Miechocin (1), Opatowiec (3), Wojnicz (3) i Zator (1).

Nie negując wartości powyższych danych o planowanych misjach, wydaje się, że ważniejsza od nich była inna informacja. Myślę tu o informacji dotyczącej czterech parafii, która mówi o potrzebie przeprowadzenia misji, ewentualnie potrzebie prowadzenia katechizacji. W gre wchodziły następujące parafie: Miechocin (dek. Miechocin), Ostrowy Baranowskie (dek. Miechocin), Porąbka Uszewska (dek. Wojnicz) i Modlnica (dek. Skała). W dwu pierwszych nie było formalnych misji, lecz, jak utrzymuje źródło, powinny być przeprowadzone. Zwłaszcza w tej drugiej potrzeba ich była szczególnie odczuwana. Wskazuje na to podkreślenie przez autora źródła dodatkowego faktu mówiącego o tym, że ludność jej mieszkała wśród lasów. Dosłowny tekst źródła dla tej parafii brzmial: „[Missio] non fuit, sed debet esse inter populum sylvestrem". Można przyjąć, że z tego powodu ludność tej parafii zapewne rzadziej uczęszczała do kościoła. To na pewno odbiło się na jej poziomie religijnym. W trzeciej parafii, tzn. w Porąbce Uszewskiej, podobnie jak w poprzednich nie przeprowadzono misji i była ona bardzo pożądana, a proboszcz zabiegał o nią od dawna (,,non exstat sed desideratur et pridem expetitur a Parocho"). Jeżeli chodzi o czwartą parafię, czyli o Modlnicę, gdzie również nie było misji, widziano tylko wielką potrzebę prowadzenia katechizacji (,non exstat [missio] et summe necessaria ad hanc parochiam pro instructione catechistica populi").

$\mathrm{Z}$ powyższych danych zupełnie jednoznacznie wynika, że w pierwszej połowie XVIII w. ceniono bardzo misje ludowe i zdawano sobie 


sprawę z tego, że brak ich nie może uchodzić za rzecz normalną. Z tego właśnie powodu uważamy owe informacje za ważniejsze aniżeli dane dotyczące misji już zaplanowanych. Podczas gdy pierwsze służą tylko do oddania istniejącej sytuacji, to drugie pozwalają na poznanie sądów i opinii o misjach, jakie mieli współcześni w jakimś stopniu za nie odpowiedzialni.

Kolejne zagadnienie, które pragniemy rozpatrzyć stanowi sprawa terminów głoszenia misji i długości ich trwania. Nasze źródło przekazuje kilka informacji, które pozwolą, jeśli nie na rozwinięcie, to przynajmniej na zasygnalizowanie powyższych kwestii.

Zebrane dane sugerują, że nie było stałych terminów głoszenia misji. Przeprowadzano je we wszystkich porach roku. Jeśli można mówić o pewnym uprzywilejowaniu niektórych okresów, to zasadniczo dotyczyło to dwu okresów: Wielkiego Postu i Wielkanocy. Na 14 misji, co do których mamy dane czasowe, w czasie Wielkiego Postu przeprowadzono ich 3 , a na Wielkanoc $-5^{15}$. $\mathrm{Z}$ pozostałych pięciu: 3 przeprowadzono $\mathrm{w}$ miesiącu październiku i 2 - w listopadzie, z tym że jedna z tych ostatnich przeciągnęła się jeszcze na grudzień.

Jak wiadomo misje niekiedy łączono $\mathrm{z}$ innymi uroczystościami religijnymi, takimi jak jubileusze, wizytacje biskupie czy akt wprowadzenia bractwa. W naszym wypadku takie okoliczności są znane tylko dla dwu misji: w parafii Górka (dek. Proszowice) i w parafii Imbramowice (dek. Skała). W pierwszej parafii była to misja jubileuszowa. W drugiej podjęto ją $\mathrm{z}$ okazji konsekracji kościoła. Ile spośród pozostałych misji było połączonych $\mathrm{z}$ dodatkowymi uroczystościami, niestety nie jest nam znane. Zapewne niezbyt wiele, gdyż większość misji była podejmowana w ramach pracy duszpasterskiej zakonów. Momentem decydującym o podejmowaniu i prowadzeniu misji ze strony zakonów była ich gorliwość oraz możliwości duszpasterskie i czasowe.

Jeżeli chodzi o drugi problem, o czas trwania misji, to występuje pod tym względem całkowita zgodność $\mathrm{z}$ informacjami na ten temat, zawartymi w dotychczasowej literaturze. Czas trwania misji wahał się od dwu do czterech tygodni. Bowiem na 8 misji o znanym czasie ich trwania: dwie trwały po dwa tygodnie, trzy po trzy tygodnie i trzy po cztery tygodnie. Podobne okresy trwania misji, jako najczęściej występujące, notuje również dotychczasowa literatura ${ }^{10}$.

Przedstawiony problem misji w pierwszej połowie XVIII w. w die-

15 Do misji przeprowadzonych $w$ wymienionych okresach zaliczyliśmy nie tylko te, dla których jest to wyraźnie stwierdzone, że były w tych okresach, ale także inne, wygłoszonel w miesiącach, na które przypadały te okresy roku liturgicznego. 10 J. Fla ga, jw., s. 192-194; M. B án bula, Liturgia na misjach ludowych $i w$ duszpasterstwie parafialnym Zgromadzenia Księży Misjonarzy w Polsce 1651-1864, „Nasza Przeszłość” 45 (1976) s. 240. 
cezji krakowskiej nie wyczerpuje wprawdzie tej problematyki, niemniej jednak wnosi wiele cennych informacji do tego bogatego kulturalno-religijnego zjawiska, którego nie można poznać $w$ inny sposób. Rzuca też nieco światła na działalność duszpasterską zakonów, tak ważną w XVIII wieku, kiedy to zakony krytykowano za ich małą przydatność. Nie ma potrzeby podkreślać, że dla właściwej oceny przedstawionej tutaj sytuacji w zakresie misji ludowych $\mathrm{w}$ diecezji krakowskiej konieczna jest znajomość sytuacji pod tym względem w innych diecezjach. Niestety jest to bardzo trudne. Diecezja krakowska jest bowiem jedyną, która posiada tego typu źródło. To oczywiście nasuwa potrzebę badań nad misjami w oparciu o inne typy źródeł, w tym przede wszystkim zakonnych.

DIE GEOGRAPHIE DER VOLKSMISSIONEN IN DER DIÖZESE KRAKAU IN DER 1. HÄLFTE DES 18. JH. IM LICHTE DER PFARREITABELLEN DES BF. A. S. ZAEUSKI

\section{Zus a m me n f as ung}

Im Lichte der bisherigen Literatur kann man nicht sagen, dass das Problem der inneren Missionen, auch Volksmissionen genannt, in Polen nicht aufgegriffen wurde. Die Literatur auf diesem Gebiet, sowohl die ältere wie auch die neuere, ist schon recht zahlreich, wenn auch weiterhin bescheiden angesichts der Bedeutung des Phänomens selbst. Die inneren Missionen wurden in der Regel von den Orden durchgeführt. Deshalb wurden fast alle Forschungen zu den Missionen im Rahmen der Ordensforschung unternommen.

Im vorliegenden Artikel wird eine etwas andere Art des Herangehens an diese Problematik präsentiert. Ausgangspunkt sind nicht die Orden, sondern das Gebiet der Diözese, konkret: der Krakauer Diözese. Als Untersuchungsgrundlage dienen die auf Anordnung des Bischofs dieser Diözelse, A. S. Załuski, angefertigten Pfarreitabellen aus den Jahren 1747-1749.

Lus dem gestültzt auf die erwähnten Tabellen durichigeführten Vergleichen ergibt sich, dass die Missionssituation in der Diözese Krakau nicht gerade bestens aussah. Von den insgesamt 756 in den Tabellen aufgeführten Pfarreien wurden in der 1. Hälfte des 18. Jahrhunderts nur in 174 Missionen durchgeführt. Das bedeutet, dass in einem Zeitraum von etwa 50 Jahren kaum $23 \%$ aller Pfarreien von iden Missionen erfalsst wurden. Die meisten Pfarreien, in denen in Uttersuchungszeitraum Missionen durchgeführt wurden, lagen in zwei Regionen der Diözese: im Gebiet nordwestlich von Krakau und in dem an der Nordgrenze der Diözese gelegenen Dekanat Parczew. Im untersuchten halben Jahrhundert führten nur zwei Orden Volksmissionen auf dem Gebiet der Krakauer Diözese durch: die Jesuiten und die Missionare. Andere Orden werden in den Tabellen nicht erwähnt. Die Missionen dauerten meistens zwischen zwei und vier Wochen. 
Natürlich ist für eine richtige Einschätzung der vorgestellten Situation im Bereich der Volksmissionen in der Krakauer Diözese die Kenntnis der Situation in den anderen Diözesen unumgänglich. Diese Angelegenheit bedarf jedoch besonderer, auf andere Arten von Quellen gestützter Untersuchungen, da die erwähnten Tabellen nur für die Diözese Krakau existieren. 